\title{
Drs. Haackert Prize 1999 Awarded to Prof. Juri Wladimiroff, The Netherlands
}

The Drs. Haackert Prize for Prenatal Medicine is awarded annually from assets of the Drs. Günther and Annemarie Haackert Foundation in Germany. The 1999 Gold Medal for Lifetime Achievements in the field of Prenatal Diagnosis and Therapy was given to Prof. Juri Wladimiroff from Rotterdam in the Netherlands at the Annual Postgraduate Education Academy which took place in Düsseldorf in February 1999 by Prof. Wolfgang Holzgreve, the Editorin-Chief of this Journal. The following eloge on Prof. Wladimiroff was written by a.o. Prof. Christoph Brezinka from Innsbruck who is one of the students of this year's laureate.

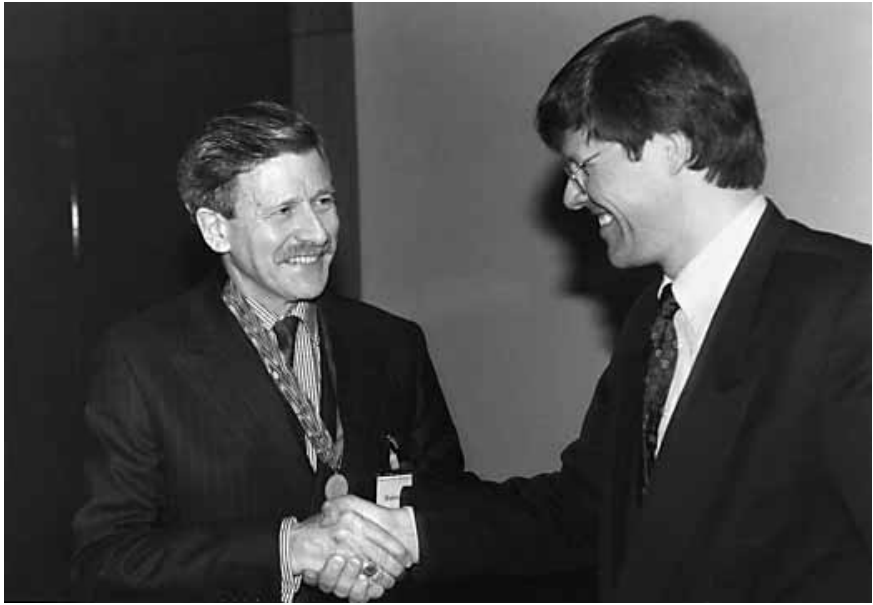

Fig. 1. Prof. Juri Wladimiroff, Rotterdam (left) received the 1999 Gold Medal of the Drs. Haackert Foundation from Prof. Wolfgang Holzgreve, Basel for his outstanding contributions in prenatal medicine.

\section{Eloge on Prof. Juri Wladimiroff}

Prof. Wladimiroff was born in The Hague in 1939. His grandparents had fled with their children from their home in St. Petersburg in 1917, first to Vladivostok, and then in 1921 to Java in what was then the Dutch East Indies and is now Indonesia. In 1933, the family moved to Holland and settled in The Hague. Juri, the eldest of three brothers, studied medicine in Leiden where he graduated in 1965. After serving as military doctor in the Dutch army he began to specialize in obstetrics and gynecology at the Westeinde Hospital in The Hague in 1967 and received his certificate as obstetrician-gynecologist in 1972.

Shortly afterwards he left with his family for Britain and took up a research fellowship at Queen Charlotte's Maternity Hospital in England. He refers to this period in which he worked with Stuart Campbell on ultrasound as the basis of everything that was to come later. In 1974, he received his $\mathrm{PhD}$ at the University of Nijmegen with a thesis on fetal monitoring.

In 1973, he started work as a consultant at the department of obstetrics and gynecology of Erasmus University Rotterman at Dijkzigt Hospital; in 1977, he was appointed reader at this department, and in 1980 full professor. Since 1984, he was head of the division of prenatal diagnosis and since 1996, when the two divisions were merged, head of the division of obstetrics and prenatal diagnosis at Rotterdam University Hospital.

Prof. Wladimiroff is one of the big names in obstetrical ultrasound. Any author attempting to write a review article on any aspect of prenatal ultrasound will find it very

\section{KARGER}

(c) 1999 S. Karger AG, Basel

Fax +41613061234

E-Mail karger@karger.ch www.karger.com
Accessible online at: www. karger.com/journals/fdt 
difficult if not impossible not to cite a number of the more than 300 publications which Prof. Wladimiroff wrote either as first author or as senior author. In addition, he has written several books in Dutch and in English.

Since 1977, he has supervised $25 \mathrm{PhDs}$ on many different aspects of prenatal diagnosis, of obstetrical, gynecological and Doppler ultrasound, and of fetal monitoring. His PhD students came from Holland, Switzerland, Britain, Indonesia and Austria. On the occasion of the 25th $\mathrm{PhD}$ his former disciples published a liber amicorum for Prof. Wladimiroff which, however, is unfortunately only available in Dutch.

Prof. Wladimiroff is one of the most active scholars in the world of prenatal diagnosis and fetomaternal medicine both on a national and an international level. At the medical faculty of Erasmus University he is associate dean with research as his portofolio. From 1993 to 1995, he was president of the Dutch society of Obstetrics and Gynecology, since 1987 he is a permanent member of the Dutch Health Council and active in several subcommittees of these organizations. $\mathrm{He}$ is an executive board member of the European Board and College of Obstetrics and Gynecology and has carried out visitations in departments from Slovenia to Portugal. He is chairman of the education committee of ISUOG and member of several FIGO working parties and panels.

$\mathrm{He}$ is member of the editorial board of a dozen scientific journals and corresponding referee for as many journals. He is also referee for grant applications in the Netherlands, Canada and England.

He is honorary member of several national ultrasound societies from Russia to Egypt. Prof. Wladimiroff is honorary professor at the university of Zagreb in Croatia. In 1996, during the ISUOG conference, which he organized in Rotterdam, he was awarded the Ian Donald Memorial Gold Medal, the highest distinction in ultrasound.
He closely cooperates with the University of Jakarta in Indonesia where he has co-supervised several PhDs, with the University of Salt Lake City in Utah and, most notably, with clinical and research institutions in his grandparents' homeland, Russia. Prof. Wladimiroff had learned Russian as a young boy from his parents and grandparents and has now seen this skill greatly appreciated after the fall of the iron curtain. Every week Russian doctors as well as Russian patients come to seek him in Rotterdam.

Prof. Wladimiroff even contributed a new word to the Dutch language: in a televsion debate on whether pregnant women should be given ultrasound examinations without any specific clinical or screening purpose, he critized this concept and called these examinations 'pretechos', literally meaning 'ultrasounds for fun'. The word fitted so well - pret has a slightly frivolous conotation as in pretpark for funpark - that it has now become part of the vocabulary in debates on health care.

Prof. Wladimiroff still amazes everyone with his energy and his productivity none of which show any sign of abating. As always, there are several articles, projects and PhDs in the pipeline.

At the award ceremony in Düsseldorf for the Drs. Haackert medal in February 1999, he held a magistral lecture on the organization of ultrasound screening during pregnancy in the Netherlands - delivered in flawless German. Prof. Wladimiroff has done so much to breach frontiers, to open doors, to facilitate the exchange of people, ideas and technologies throughout Europe and the former Soviet Union. The Drs. Haackert medal will certainly not be the last medal that he shall be awarded for past, present and future achievements.

Christoph Brezinka, Innsbruck 